IZA DP No. 6384

Is Religiosity of Immigrants a Bridge or a Buffer in the Process of Integration? A Comparative Study of Europe and the United States

Teresa Garcia-Muñoz

Shoshana Neuman

February 2012 


\title{
Is Religiosity of Immigrants a Bridge or a Buffer in the Process of Integration? A Comparative Study of Europe and the United States
}

\author{
Teresa Garcia-Muñoz \\ University of Granada \\ Shoshana Neuman \\ Bar-llan University, \\ CEPR and IZA
}

Discussion Paper No. 6384

February 2012

\author{
IZA \\ P.O. Box 7240 \\ 53072 Bonn \\ Germany \\ Phone: +49-228-3894-0 \\ Fax: +49-228-3894-180 \\ E-mail: iza@iza.org
}

\begin{abstract}
Any opinions expressed here are those of the author(s) and not those of IZA. Research published in this series may include views on policy, but the institute itself takes no institutional policy positions.

The Institute for the Study of Labor (IZA) in Bonn is a local and virtual international research center and a place of communication between science, politics and business. IZA is an independent nonprofit organization supported by Deutsche Post Foundation. The center is associated with the University of Bonn and offers a stimulating research environment through its international network, workshops and conferences, data service, project support, research visits and doctoral program. IZA engages in (i) original and internationally competitive research in all fields of labor economics, (ii) development of policy concepts, and (iii) dissemination of research results and concepts to the interested public.
\end{abstract}

IZA Discussion Papers often represent preliminary work and are circulated to encourage discussion. Citation of such a paper should account for its provisional character. A revised version may be available directly from the author. 


\section{ABSTRACT \\ Is Religiosity of Immigrants a Bridge or a Buffer in the Process of Integration? A Comparative Study of Europe and the United States}

This study reviews and evaluates the intertwined relationship between immigration and religiosity, focusing on the two sides of the Atlantic - Europe and the United States. Based on the existing literature and on a statistical analysis of several data sets (the International Social Survey Program - ISSP: Module Religion, 2008; the European Social Survey - ESS, waves 2002-2010; and the General Social Survey - GSS, waves 2002-2010) the following aspects are explored: (i) the current religious landscape of Europe and of the United States and projections for the future; (ii) religiosity of immigrants (in Europe and the United States): are they more religious than the native populations (in terms of church attendance and of prayer habits)?; (iii) how does religiosity of immigrants affect integration: is it serving as a bridge that smoothens integration into the local population, or as a buffer against the harsh integration process?; and (iv) are the intersections between religiosity and integration different in Europe and in the United States, due to historical differences in the state-religion relationship, immigration policies and concepts? The main findings are the following: (a) immigrants are indeed more religious than the populations in the receiving countries. This fact, combined with higher fertility rates and also a continued inflow of immigrants, will lead to major changes in the religious landscape, both in Europe and in the United States; and (b) while in the united States religiosity of immigrants serves as a bridge between the immigrants and the local population, in Europe it has mainly the function of a buffer and of "balm to the soul".

JEL Classification: J11, J15, Z12, Z13

Keywords: immigration, religion, integration, Europe, United States

Corresponding author:

Shoshana Neuman

Department of Economics

Bar-llan University

52900 Ramat-Gan

Israel

E-mail: neumans@mail.biu.ac.il

\footnotetext{
* Part of this Discussion Paper will be included in The International Handbook on the Economics of Migration (edited by Amelie Constant and Klaus F. Zimmermann), published by Edward Elgar Publishing Limited. Our thanks to the editors of the handbook and to two referees, for their very helpful comments and suggestions. Shoshana did part of this study during her stay at IZA (summer 2011). She would like to thank the IZA Institute for its hospitality and excellent research facilities. In particular, Margard Ody (the Information Manager) and Sarah Ewerts (Trainee), for providing many of the articles used for the study. Teresa would like to thank MICINN (ECO2010-17049) and Junta de AndalucíaExcelencia (P07.SEJ.02547), for financial support.
} 


\section{Introduction and motivation}

A heated political and intellectual debate is taking place in Europe on the effects of immigration influxes. The debate has focused on the costs and benefits of cultural/religious diversity, rather than on the economic costs and benefits of immigration. The assumption that motivates the debate is that immigrants' religious behavior is fundamentally different from that of the native born, in particular if they belong to a denomination that is not one of the country's major religious denominations. This assumption is supported by studies on the cultural/religious transmission of norms and attitudes. The transmission process takes place mainly during childhood and has two venues: direct transmission - across generations, by parents; and oblique transmission - within generations, by the individual's community and cultural/religious environment (e.g., Bisin and Verdier, 2000, 2001; Bisin at al., 2008; Bar-El et al., 2012). It follows that immigrants are most probably equipped with different social/religious capital compared to the native population, as the norms and attitudes of their parents and childhood environment differed from those at the current place of residence. Social/religious norms seem to be quite rigid and persistent and therefore second-generation immigrants might also exhibit a different religious identity than the natives.

In many cases, the 'otherness' of immigrants leads to profound social/religious tension. Such tensions are exacerbated by prejudice against immigrants in general, and by anti-Moslem prejudice in particular. In recent years a series of international events has led to ever increasing attention to Islam and Moslems in public discussion in Europe and also in the United States. Hostility against Moslem communities increased significantly in the aftermath of September $11^{\text {th }}$, in the United States and also in many European countries (Allen and Nielsen, 2002; Fetzer and Soper, 2003; Sheridan and Gillett, 2005), although even before September $11^{\text {th }}$ prejudice against Moslems was more widespread than prejudice against other immigrants (see Strabac and Listhaug, 2008 in a review article of 30 countries). The projections for the future are that the demographic trend of a growing share of the Moslem populations in Europe is expected to result in a further increase in anti-Moslem taste-based discrimination (Adida, Laitin and Valfort, 2011). ${ }^{1}$

\footnotetext{
${ }^{1}$ Using experimental games (conducted in France) and a formal model, they show that hostility toward Moslems significantly increases with Moslem out-group salience. No such effect is found for the impact of Christian outgroup salience. The authors claim that this result lends support to group-threat theory.
} 
This study aims to first review and evaluate the literature on the intertwined relationship between immigration and religiosity, focusing on the two sides of the Atlantic - Europe and the United States.

Based on the existing literature and on a statistical analysis of several data sets (the International Social Survey Program - ISSP: Module Religion, 2008; the European Social Survey - ESS, waves 2002-2010; and the General Social Survey - GSS, waves 2002-2010) we aim to explore the following aspects: (i) the current religious landscape of Europe and the United States and projections for the future; (ii) religiosity of immigrants (in Europe and the United States): are immigrants more religious than the native population?; (iii) religiosity and integration into the local populations: is religiosity serving as a bridge between immigrants and the populations in the receiving countries, or mainly as: "balm to the soul", a buffer against the hardships of integration, and as bonding social capital within the immigrants' community?; and (iv) is the intersection between religiosity and integration different in Europe and in the United States, due to historical differences in the state-religion relationship, immigration policies and concepts?

The structure of the chapter is the following: the next section presents background information and figures on immigration and religiosity in the United States and Europe, including projections for the future. The third section includes a theoretical discussion on alternative effects of immigrants' intensified religiosity (which are shaped by the culture/history and the religious landscape of the host country - the United States versus European countries). An empirical analysis follows in the fourth section, while the last section summarizes and concludes.

\section{Immigration, religiosity, and the religious landscape - facts, figures and projections for the future}

The United Nations reports that in 2010 more than 213 million people, or 5\% of the world population, lived and worked in a country in which they were not born. Moreover, the flow of immigrants has constantly increased over the last two decades. In 1990, The United Nations estimated that the number of migrants was 154.8 million people, while in 2005 this figure grew to 190.6 million people. ${ }^{2}$

\footnotetext{
${ }^{2}$ Given these impressive figures, economists (along with researchers from other disciplines) address the causes and consequences of these flows. Topics of interest for immigration economists are changing, possibly as a
} 
In the last several decades, the United States and Western Europe have become the main destinations of immigrant flows, and they will be the focus of this study. ${ }^{3}$

The United Sates has a long tradition of immigration. In the $19^{\text {th }}$ century and in the early $20^{\text {th }}$ century, immigrants came mainly from Europe, while more recent immigrants originate primarily from Asia and the Americas. The top five sending countries in 2010 were Mexico, China, India, the Philippines, and the Dominican Republic (US Department of Homeland Security). Figure 1 presents immigration flows (measured by numbers of immigrants who received the status of "legal permanent resident") into the United States during the last decade (2001-2010). Clearly, Asia ranks highest, and in most recent years, Europe ranks lowest. The figures for Asia are more than 4 times larger than parallel figures for Europe.

Figure 1: People obtaining "legal permanent resident status" in US

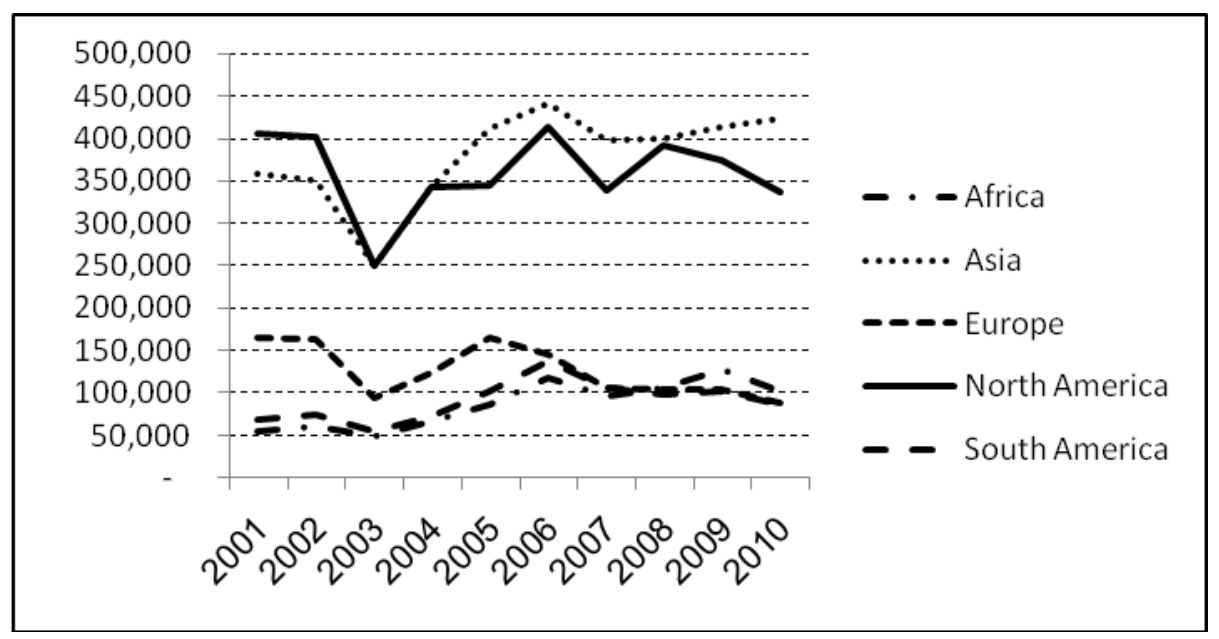

Source: US Department of Homeland Security

For Western Europe, the new immigration trend means a drastic reversal of a long history of emigration to the rest of the world, and in particular to the United States. ${ }^{4}$ Western Europe changed its immigration status - from a 'sending' society to a 'receiving' center.

result of public perceptions of immigration. For instance, between 1990 and 1994 the most popular topic in the nine top economic journals was immigrant assimilation. Between 2005 and 2009 the most common topic was immigrants' effect on natives' labor market outcomes (Lozano and Steinberger, 2010).

${ }^{3}$ Another country that received very large waves of immigration is Israel. It is most probably the only country in the world where the receiving population (about 649,500 on May 15, 1948 - the day of statehood) absorbed within 3.5 years an immigration wave that was larger than the native population, and arrived from all over the globe. Between May 15, 1948 to and the end of 1951, a total of 687,624 immigrants joined the tiny local population, leading to an annual population growth rate of $22.7 \%$ and more than doubling the population within 3.5 years. Immigration slowed down but never ceased. Annual population growth rates (due to immigration) were around $2 \%$. In the late 1980s, another major wave of more than 1 million immigrants from the former USSR entered the country, leading to an increase of about $20 \%$ in population size $(6.2 \%$ during the few last months of 1989, 5\% in 1991, and annual growth rates of about 2.5\% from 1992 until the end of the 1990s) (Neuman, 2005; Tables 13.1 and 13.7). 
There were several sources to the immigration flows into Western Europe: immigrants from their former colonies (in North and West Africa, and South- and Southeast Asia) arrived in France, England and the Netherlands; migrant labor from the less developed Southern European countries (Italy, Spain, Portugal, Greece, Yugoslavia, and Turkey) were attracted by “guest-workers" programs ${ }^{5}$; refugees, asylum seekers and illegal migrants fled (and are still fleeing) less privileged regions that suffered from famines, wars and political violence; and immigrants from the Former Soviet Union and Eastern Europe left their native countries when the gates opened after the collapse of communism in $1989 .{ }^{6}$

Countries changed status also within Europe from 'sending' to 'receiving' countries. Figure 2 presents the path of the annual rate of change in the 'stock' of immigrants in Germany, Italy, Spain and Great Britain during the last two decades:

Figure 2: Annual rate of change of the 'stock' of immigrants (\%)

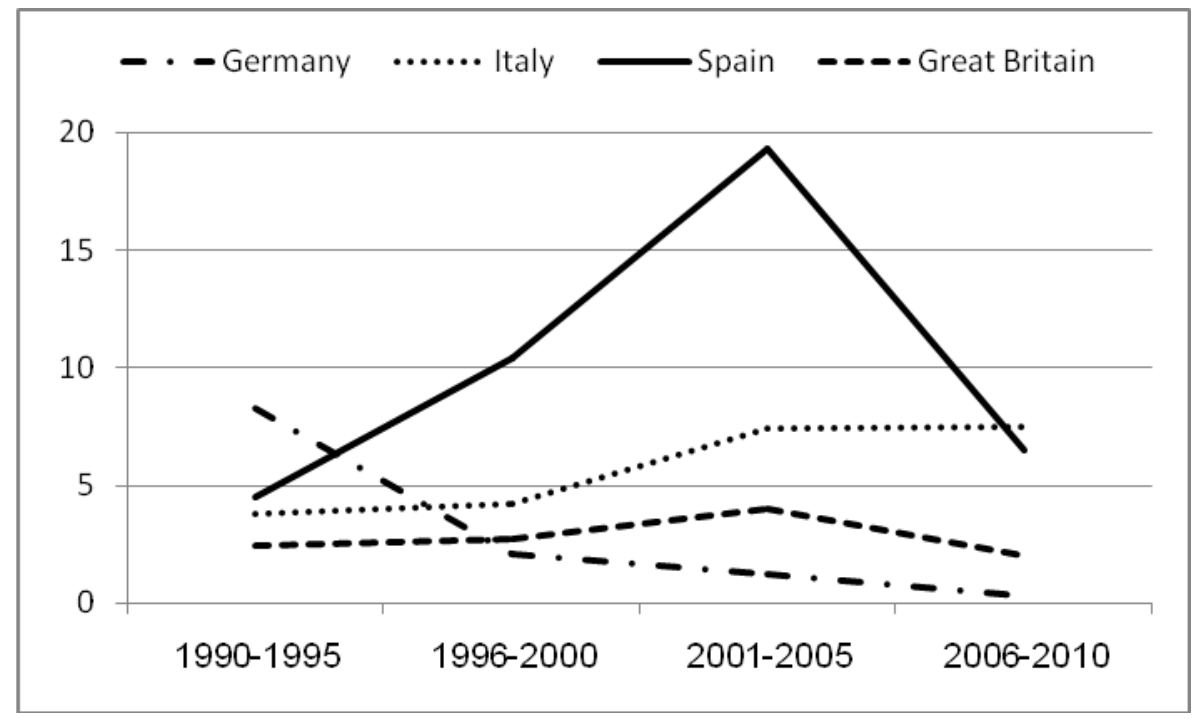

Source: United Nations, Department of Economic and Social Affairs

\footnotetext{
${ }^{4}$ It is estimated that about 85 million Europeans immigrated to the New World and the Southern Hemisphere during the period of 'industrialization' (the 1800s to the 1920s), 60\% of them to the United States (Casanova, 2006).

${ }^{5}$ Germany’s postwar guest worker program began in 1955 when Germany signed a labor recruitment agreement with Italy that permitted German farmers to hire Italian guest workers. Shortly afterwards, bilateral agreements were signed with another seven recruitment countries: Greece, Portugal, Spain, Yugoslavia and also three countries outside of Europe, specifically Morocco, Tunisia and Turkey. Guest worker programs are still relevant for the admission of migrant workers from low-income countries to fill jobs in high-income countries. See Ruhn and Martin (2008) for a review and discussion.

${ }^{6}$ The heterogeneity of countries of origin led to large variations in educational attainments and wages of immigrants in Europe: immigrants from non-OECD countries have lower educational levels and wages, in particular compared to natives and to immigrants from the EU15 countries (Dustmann and Frattini, 2011).
} 
In recent years (since the year 2000) traditional receiving countries, such as Germany and Great Britain, exhibited decreasing (although positive) annual rates of change in the 'stock' of immigrants. Spain and Italy lie well above Germany and Great Britain in terms of growth rates of the immigrant pool. Spain reached a maximum of almost 20\% around the year 2000 . Since 2001 there has been a drop in the annual growth rates of immigrant stocks in Spain(from $19.3 \%$ to $6.5 \%$ ). However the figures are still impressive. In most recent years, the growth rates in the stock of immigrants were around 7\% in Spain and Italy, almost zero in Germany and about 2\% in Great Britain.

More information can be gained from Table 1 which presents the sizes (in 1000s) of foreignborn populations in Europe, in 2010. As the Table indicates, immigrants comprise more than $10 \%$ of the local population in a large number of European countries. In the top ranks we find Luxembourg (32.5\% of the population are immigrants), Cyprus (18.8\%) and Estonia (16.3\%). In few countries the shares of immigrants are below 5\% (Slovakia ranks last where immigrants comprise only $0.9 \%$ of the total population). The majority of immigrants were born in non-European countries. 
Table 1: Foreign-born populations in Europeby country, 2010

\begin{tabular}{lccc}
\hline Country & $\begin{array}{c}\text { Number of } \\
\text { foreign born } \\
(1000 s)\end{array}$ & $\begin{array}{c}\text { Share of foreign } \\
\text { born in total } \\
\text { population(\%) }\end{array}$ & $\begin{array}{c}\text { Born in non-European } \\
\text { countries }\end{array}$ \\
(\% in total population)
\end{tabular}

Source: Eurostat (online data access: tps00178, migr_pop3ctb)

Notes: Data are not available for Bulgaria, Croatia, Switzerland and Ukraine. The Slovakian data are for the year 2009. The Belgian data are provisional.

One of the most pronounced consequences of the new immigration to the United States and to Europe, has been the growth in religious diversity. The United States already had a religiously-diverse population and religious pluralism, while Europe had limited religious pluralism and therefore the change due to immigration was much more significant.

Table 2 displays information on the two major religions - both within the native population and within the first-generation immigrant populations. ${ }^{7}$

\footnotetext{
${ }^{7}$ The term 'first-generation immigrants' refers to immigrants whose parents and they too were born outside the current country of residence. 'Second-generation immigrants' were born in the current country of residence but their two parents were born in other countries.
} 
Table 2: Major religions among natives and among first-generation immigrants, in European countries and the United States, 2002-2010

\begin{tabular}{|c|c|c|c|c|}
\hline \multirow[b]{2}{*}{ Country } & \multicolumn{2}{|c|}{ Natives } & \multicolumn{2}{|c|}{ First-generation immigrants } \\
\hline & $\begin{array}{l}\text { First largest } \\
\text { religion }\end{array}$ & $\begin{array}{l}\text { Second largest } \\
\text { religion }\end{array}$ & $\begin{array}{l}\text { First largest } \\
\text { religion }\end{array}$ & $\begin{array}{l}\text { Second largest } \\
\text { religion }\end{array}$ \\
\hline Austria & Catholic & Protestant & Catholic & Islam \\
\hline Belgium & Catholic & Other-Christian & Catholic & Islam \\
\hline Bulgaria & Orthodox & Islam & Orthodox & Islam \\
\hline Croatia & Catholic & Orthodox & Catholic & Orthodox \\
\hline Cyprus & Orthodox & Catholic & Orthodox & Catholic \\
\hline The Czech Rep. & Catholic & Protestant & Catholic & Other-Christian \\
\hline Denmark & Protestant & Other-Christian & Islam & Protestant \\
\hline Estonia & Protestant & Orthodox & Orthodox & Catholic \\
\hline Finland & Protestant & Other-Christian & Protestant & Orthodox \\
\hline France & Catholic & Protestant & Catholic & Islam \\
\hline Germany & Protestant & Catholic & Catholic & Islam \\
\hline Greece & Orthodox & Islam & Orthodox & Islam \\
\hline Hungary & Catholic & Protestant & Catholic & Protestant \\
\hline Ireland & Catholic & Protestant & Catholic & Protestant \\
\hline Italy & Catholic & Protestant & Catholic & Islam \\
\hline Latvia & Catholic & Protestant & Orthodox & Catholic \\
\hline Luxembourg & Catholic & Other-Christian & Catholic & Other-Christian \\
\hline The Netherlands & Catholic & Protestant & Islam & Catholic \\
\hline Norway & Protestant & Other Christian & Islam & Protestant \\
\hline Poland & Catholic & Orthodox & Catholic & Islam \\
\hline Portugal & Catholic & Other-Christian & Catholic & Other-Christian \\
\hline Russia & Orthodox & Islam & Orthodox & Islam \\
\hline Slovakia & Catholic & Protestant & Catholic & Protestant \\
\hline Slovenia & Catholic & Protestant & Catholic & Orthodox \\
\hline Spain & Catholic & Other-Christian & Catholic & Islam \\
\hline Sweden & Protestant & Other-Christian & Islam & Protestant \\
\hline Switzerland & Protestant & Catholic & Catholic & Protestant \\
\hline Ukraine & Orthodox & Catholic & Orthodox & Islam \\
\hline United Kingdom & Protestant & Catholic & Catholic & Islam \\
\hline United States & $\begin{array}{l}\text { Evangelical- } \\
\text { Protestant }\end{array}$ & Catholic & Catholic & $\begin{array}{l}\text { Evangelical- } \\
\text { Protestant }\end{array}$ \\
\hline
\end{tabular}

Source: ESS and GSS, waves 2002-2010.

Note: Catholic refers to 'Roman Catholic'. 'Other-Christian' is a Christian denomination other than Catholic, Protestant, or Orthodox.

As is evident from Table 2, immigration leads to a change in the religious landscape of many European countries. The major change is the increasing share of Moslems. When the native populations are examined, Islam is found to be the second largest religion in only three countries (Bulgaria, Greece and Russia). Within first-generation immigrant populations, the distribution of religions is very different: In four countries Islam is the first largest religion 
(in the Scandinavian countries of: Denmark, Norway and Sweden, and also in the Netherlands). In another 12 countries Islam is the second largest religion.

Based on the demographic advantage of the religious populations caused by (i) the dramatic decrease in fertility rates within secular native European populations, which is combined with (ii) high fertility rates among the religious populations, and coupled with (iii) the immigration of more religious groups into secular countries - the long-term consequences will be a constant change in the religious makeup, with a growing share of more religious residents in general and of members of Islam faith in particular. Moreover, lower secularization rates within the immigrant population (in particular among Moslem immigrants) ${ }^{8}$ will also lead to some reversal of the secularization phenomenon in Europe (de-secularization).

Some figures can further illustrate the above proposition: during the last decades, most European countries have faced a dramatic drop in fertility rates. Eurostat data show that, the number of live births in Europe in 1970 was 7.15 million babies, while in 2010 this figure decreased to 5.36 million. The most pronounced changes in the average number of live births per woman are evidenced in the European Catholic countries: Ireland (from 3.8 in the early 1970sto 2.1 in 2010), Spain (from 2.2 in the early 1980s to 1.4 in 2010), Portugal (from 3.0 in the early 1970s to 1.4 in 2010), Italy (from 2.4 in 1970 to 1.4 in 2009), and Poland (from 2.1 in 1990 to 1.4 in 2010).There was a marginal small decrease in fertility in the United States: from 2.2 births per woman in 1970 to 2.1 in 2009 (United Nations, Population Division). Lesthaeghe and Neidert (2006) point out that immigrants and religious conservatives are responsible for the relatively high fertility of the United States compared to that of other industrialized countries.

Fertility rates are significantly higher within the immigrant populations. An examination of national country measures shows that: in the UK in 2010, the Total Fertility Rate (TFR) of UK-born mothers was 1.88 versus 2.45 for non-UK born mothers (Office for National Statistics-ONS, UK); in Sweden in 2010, the TFR for Swedish mothers was 1.8 compared to 2.3 for foreign mothers (Statistics Sweden); and in Switzerland in 2010, TRF measures were 1.4 and 1.9 for Swiss and foreign-born mothers, respectively (Swiss Statistical Office).These figures, coupled with the immigration of more religious groups into secular countries, are

\footnotetext{
${ }^{8}$ Secularization within the Moslem population has decreased over the years. According to ISSP data, the percentage of Moslems who 'never pray' was 27.72 in 1991, 25.07 in 1998, and only 7.23 in 2008. When attendance to religious services is considered, the percentage of Moslems who 'never attend' dropped from 35.85 in 1991 to 27.35 in 1998, and further decreased to 16.70 in 2008.
} 
expected to lead to: 1) a dramatic change in the religious composition of countries; and 2) desecularization and growing religious intensity.

1. The most dramatic anticipated change in the religious landscape in Europe and the United States is the growing share of Moslems. According to the Pew Research Center (2011), the Moslem share in the European population (as a whole) is expected to grow by nearly one-third over the next 20 years, rising from 6\% of the region's population in 2010, to 8\% in 2030. The same report projects that in the United States the number of Moslems will more than double over the next two decades, leading the country to host a larger number of Moslems than all European countries (except for Russia and France) combined.

This prediction is further developed in Goujon et al. (2006) and in Skirbekk et al. (2010). The two articles consider relative fertility, migration, and intergenerational religious transmission and offer projections for the future religious composition of Austria (in 2051) and of the United States (in 2043), respectively. Similar trends are expected in other countries as well, particularly those with high immigration rates.

The first article presents data and projections for Austria. Goujon et al. (2006) arrive at the following major estimates: the proportion of Roman-Catholics will decrease from $75 \%$ in 2001 to less than $50 \%$ by the middle of the century; the Moslem population that grew from 1\% in 1981 to $4 \%$ in 2001 will represent $14 \%-26 \%$ of the Austrian population by 2051. If current fertility trends do not change, in 2051 Islam could be the major religion of those below 15 years of age.

These projections are based on an assumption of an annual inflow of 20,000 Moslem immigrants. In other European countries that have more significant inflows of immigrants with high fertility rates (e.g. Germany, Spain), the changes in the religious composition of the country could be accelerated and more dramatic.

Skirbekk et al. (2010) also report that the low fertility of secular Americans coupled with the higher-than-average fertility rates of immigrants, will lead to a significant change in the religious make-up of the American population, and provide a countervailing force to secularization. Some of their projections are that Hispanic Catholics will experience rapid growth; Liberal Protestants will decline relative to other groups due to low fertility and losses from religious switching; immigration will drive growth among Hindus and Moslems; and low fertility and a mature age structure will cause Jewish decline. 
2. Another by-product of the change in the religious landscape will be higher religiosity in European countries and reversal of the secularization phenomenon that took place during many decades. ${ }^{9}$ Skirbekk et al. (2010) claim that also in the United States, the change in the religious/ethnic composition will cause the non-religious population share to peak before 2043 and decrease thereafter. The term de-secularization is used in many recent studies to describe a trend that reverses the long-lasting secularization trend. In his book “Shall the Religious Inherit the Earth?”, Kaufmann (2010) claims that the population of the developed world will become increasingly religious and conservative in the long term, reversing decades - even centuries - of liberal secularization. In other words, in the equilibrium between secularization and religious fertility - it is claimed that the latter dominates. Ingelhart and Norris (2004) arrive at a similar conclusion offering extensive evidence for 80 societies to support their thesis. ${ }^{10}$ Toft et al. (2011) even become lyrical when they refer to the 21st century as "God's Century".

\section{Immigrants' intensified religiosity and integration into the host country - theoretical discussion, testable hypotheses and evidence}

Our background information demonstrated the significance of immigration and its impact on the religious landscape of the receiving countries. In order to shed more light on the interrelationship between immigration and religiosity, and consequently the effects on integration, we will discuss: 1) are immigrants (in Europe and in the United States) more religious than the native populations?; and 2) if the answer to the first question is positive what are the components and consequences of the more intensive religiosity of immigrants? Also, are the dominant components different in Europe than the United States?

\footnotetext{
${ }^{9}$ The literature refers to diverse aspects of the 'secularization' concept: (i) differentiation of the major institutions of society (law, politics, economy, education, etc.) from the influence of religion; (ii) rationalization (Weber, 1930); (iii) demystification of all spheres of life; and (iv) less adherence to religious acts such as attendance to religious services and prayer. A different distinction is suggested in Sommerville (1998). He sorts the various aspects of secularization into two categories. Those presented in terms of (i) processes (i.e., decline, differentiation, disengagement, rationalization); or (ii) levels of analyses (i.e., structural, cultural, organizational, individual). Tschannen (1991) provides an inventory of the elements of classic theories of secularization. Casanova (1994) re-evaluates the theory of secularization in light of the resurgence of religion during the last decades, focusing on the phenomenon of 'de-privatization' or religious re-engagement in the public sphere. Swatos and Christiano (1999) present a comprehensive review of the secularization theory and debate. See also Bar-El et al. (2012) for a theoretical intergenerational model of secularization followed by empirical hypotheses' testing (using ISSP-1998 data).

${ }^{10}$ Ingelhart and Norris (2004)draw on a massive base of evidence generated by four waves of the World Values Survey, which was conducted from 1981 to 2001 in eighty societies and covered all the world's major denominations.
} 
1. Religiosity of immigrants: Immigrants are believed to be more religious than the native populations (e.g. Aleksynska and Chiswick, 2011). Moreover, it is even claimed that immigrants (in the United States) become more religious in their new country than they were in their home land: "immigrants are religious - by all counts more religious than they were before they left home..” (Williams, 1988, page 29).

Our first hypothesis will therefore be: Hypothesis 1: immigrants (in particular firstgeneration immigrants) are more religious than the native population, in both the United States and in Europe. They are also expected to be more religious in the receivingcountry than in their country-of-origin.

2. Religiosity of immigrants and integration in the host country - is religiosity a 'bridge' or $a$ 'buffer'? Two competing theories offer explanations for the possible motives and consequences of immigrants' intensive religiosity. The two explanations lead to different predictions about the inter-relationship between immigrant religiosity and integration into the local community: (a) the first one refers to religiosity and religious organizations as a 'bridge' that facilitates immigrant assimilation and mobility; and (b) the second one claims that religiosity and religious institutions are a 'buffer' for those immigrants that fail to integrate into the society of the host country.

a) The bridging role of religion in the process of assimilation: Herberg (1960) was probably the first who emphasized the role of religion in the process of assimilation (in the United States), arguing that religion has the potential of replacing ethnic and national identities, and thus helps the immigrants to craft an American identity. In a very similar vein, Gordon (1964) and Smith (1978) argued that immigrants used religion to smooth assimilation into the American mainstream. When immigrants define themselves in religious terms, their ethnic/national/racial differences become less pronounced, and diverse communities are brought together with the native local community through shared worship (e.g., Peek, 2005). Because religion is not strongly bound to a particular place or country of origin, religious identification could become a factor that enables newcomers to overcome social isolation. Moreover, religious institutions can help the immigrants to acquire social and civic skills that will soften the assimilation process. Activity in religious organizations creates further opportunities for civic and community engagement (Cyrus et al., 2006; Ramakrishnan and Viramontes, 2006). In addition to meeting spiritual and 
social needs, migration networks that are created through religious institutions often provide material benefits and play an important role in information transmission regarding economic opportunities in the receiving society (Borjas and Hilton, 1996; Munshi, 2003; Mayda, 2010), housing, schooling, and obtaining immigration-related papers (see Ebaugh and Chafetz, 2000, for an overview).

b) Religiosity as a 'buffer': Contrary to evidence on the positive effects of religious organizations on the process of integration and assimilation, there are also studies that document their negative effects on assimilation and adaptation. It is claimed that religion could serve as a 'buffer' (rather than a 'bridge'), which slows the process of assimilation, and serves as a 'mobility trap' (Greeley 1972; Cadge and Ecklund, 2006). Using pilot data from the New Immigrant Survey (a nationally representative sample of new legal immigrants to the United States) Cadge and Eucklund (2006) find that immigrants who are less integrated into American society (older, unemployed, speaking a non-English language at home) are more likely than others to regularly attend religious services. In a cross-national study that covers European countries, Van Tubergen and Sindradóttir (2011) find that religiosity is higher among immigrants who are unemployed and less educated. Ghazal-Read (2004) and Ramakrishnan and Viramontes (2006) claim that religiosity might be particularly limiting for immigrant women since religious attitudes and beliefs regarding gender roles (as mothers and care givers at home) prevent them from engaging in activities in the labor market and the public sphere. ${ }^{11}$ Another example in support of the negative correlation between immigrants' religious activity and their integration and adaptation is Constant et al. (2006). They look at minority ethnic groups in Germany and report that non-religious individuals perform better than religious ones. Obviously, causality could run in the opposite direction: from failure to integrate in the host country to participation in church activities, rather than the proposed causality that goes from church attendance to lower integration. Religious activities can serve as a "balm for the soul" (Connor, 2010) for those who failed to integrate into the local society and labor market.

Putnam (2000) presents related ideas and describes two types of social capital that can

\footnotetext{
${ }^{11}$ Ozyurt (2009) arrives at mixed results. She found that more intensive religiosity is a barrier for cultural integration of American Moslem women in the US, yet facilitates political/civic integration.
} 
serve as measures of prospects of immigrants' assimilation: (a) 'bridging capital' which relates to the links between communities and bridges between immigrants and native communities. More bridging capital leads to better assimilation of the immigrant community; and (b) 'bonding capital', which helps to establish close links with members within a community. As religiosity is a key component of social capital, we can apply his concepts of 'bridging capital' versus 'bonding capital' to the religious arena, and connect with the above theories of religiosity as a 'bridge' versus a 'buffer'. Those who refer to religiosity as a 'bridge' believe that religiosity should be characterized as 'bridging capital'. Researchers who claim that religion, religiosity and religious organizations are a 'buffer' and shock-absorber for immigrants argue that it is basically 'bonding capital' that helps individuals within their community, provides psychological comfort and mitigates loneliness (Chiswick, 2003; Waite and Lehrer, 2003; Connor, 2010; Lehrer, 2010).

The religious practices of immigrants most likely combine components of the two types of social capital. Church services, prayers and religious rituals provide worshipers with a familiar cyclical rhythm and represent continuity between life in the home country and life in the host country (Tiilikainen, 2003), while also helping them to establish new ties with the native population and adapt to the new country of residence. Ebaugh and Chafetz (1999) conclude that "Religious institutions are the physical and social spaces where the changes required by the new social milieu and the continuities desired by immigrant members can be achieved".

The interrelationship between immigrants' religiosity, and their integration into the local native population, is also central for long-term considerations. In particular: will the growing shares of Moslem immigrants accelerate or attenuate prejudice/distaste against the Moslem immigrant community? The literature offers two opposing theories that are closely related to the consequences of immigrants' religiosity described above: (a) The 'intergroup contact theory' predicts that an increase in the relative size of the immigrant religious group (or any other minority) provides contact opportunities between the local population and the minority religious group, which in turn diminish tension and prejudice against that group (Allport, 1954; Adida, Laitin and Valfort, 2011). If the 'bridging' factor of religiosity dominates, facilitating more contact between the native and immigrant populations, less distaste against religious minorities is expected;(b) the 'group threat theory',on the other hand, predicts that an increase in the size of the minority generates 
hostile attitudes by the dominant native group toward the minority, either because of competition over scarce resources, or because of the perception that the minority is a symbolic threat to the cultural integrity (Blalock, 1967; Adida, Laitin and Valfort, 2011). If the religiosity of immigrants is a 'buffer' against the local population, leading to less integration and contact with the native population, the 'group threat theory' will govern and more hostility against religious minorities is expected.

Which component ('bridge' or 'buffer') dominates? The answer is most probably countryspecific. Given that in this study we examine the United States versus Europe, it is helpful to first explore the fundamental differences between them. Two primary disparities between the United States and Europe are evident: (a) the different religious setting and the role of religion and religious group identities in public life; and (b) the composition of the immigration flow.

(a) Americans in general tend to be religious, more religious probably than most people in other modern societies.Using the ISSP (International Social Survey Program): Module Religion (2008), we can compare distributions of church attendance (a public religious activity)and prayer(a private/intimate religious activity) in Europe versus the United States. The ISSP is an ongoing effort devoted to cross-country research on national attitudes. The 'Religion Module'focuses on a wide range of questions related to religion and religiosity. ${ }^{12}$ Distributions of religious service attendance and of prayer in Europe versus the United States are shown in Figures 3 and 4.

Figure 3: Frequency of respondent's attendance to religious services

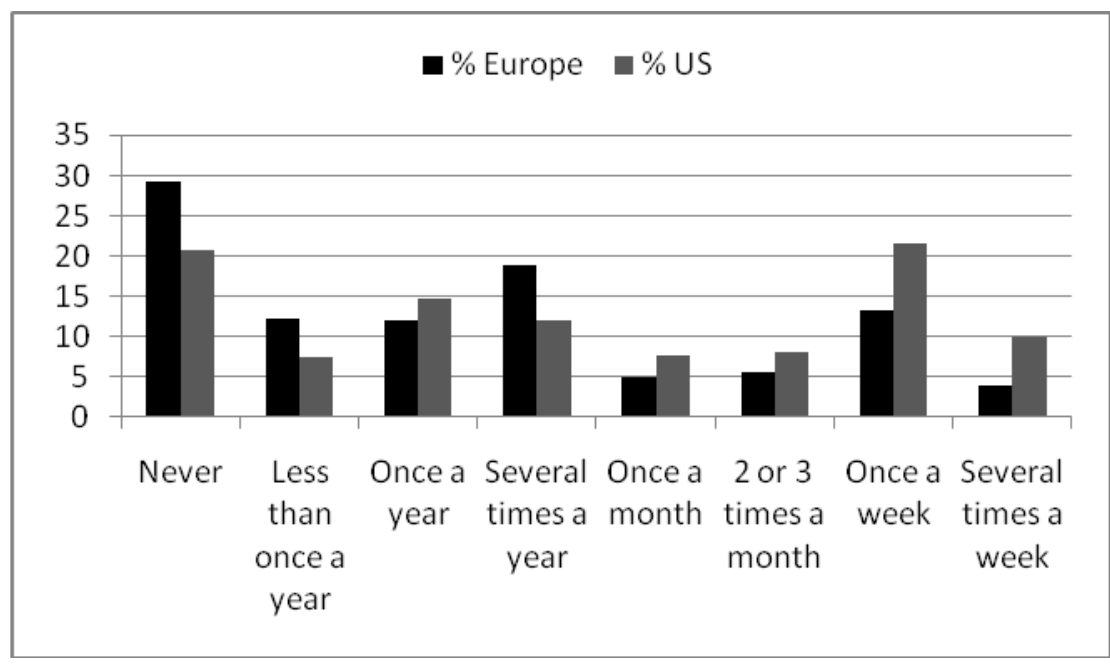

Source: ISSP 2008

\footnotetext{
${ }^{12}$ For more on the ISSP see Brañas-Garza and Neuman (2004) and Bar-El et al. (2012).
} 
Figure 3 indicates that church attendance is significantly more intensive in the US. The mode in Europe is 'never', while the mode in the United States is 'once a week'. Note however, that in the US the frequency of 'never' is quite similar to that of'once a week'. This result mirrors one of the key findings in a recent book by Putnam and Campbell (2010). The authors make the point that behind the overall high level of religiosity in the United States (which is also demonstrated by Figure 3) there is polarization, with high concentration of individuals at the two ends of the distribution: non-religious and religious conservatives.

Figure 4: Frequency of respondent's prayer habits

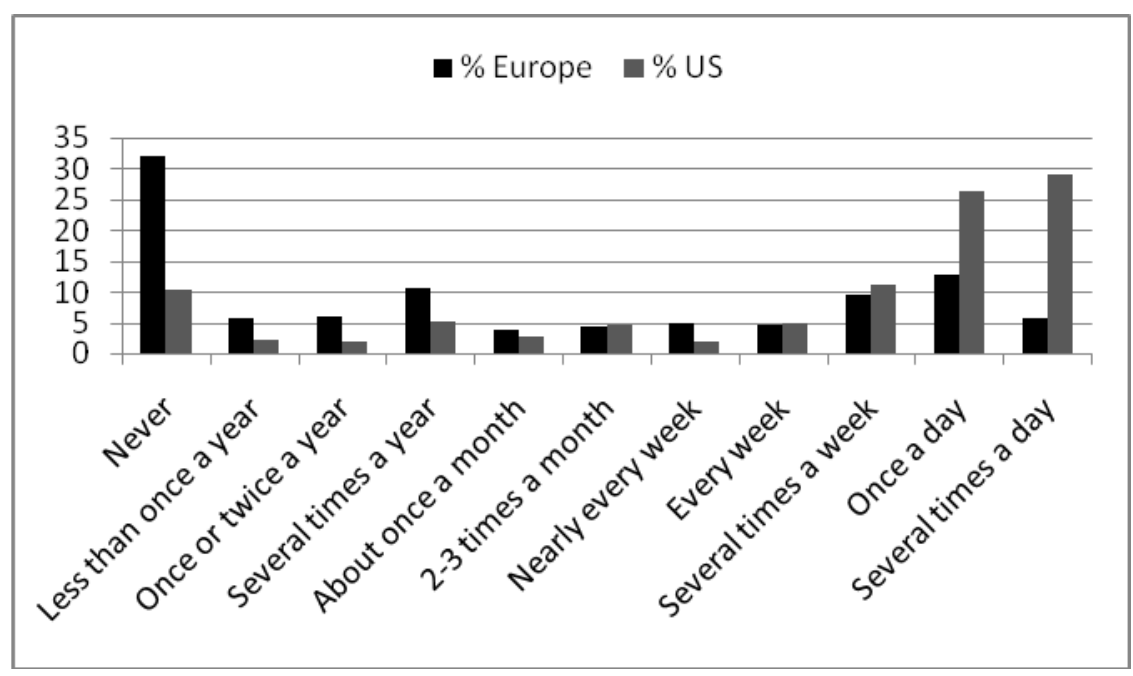

Source: ISSP 2008

The differences in religiosity are even more pronounced when prayer habits are considered. As church attendance also has networking motives, prayer is probably a better indicator of intensity of religiosity. The averages of prayer frequencies (on a scale of 1-11) are 4.97 in Europe and 8.17 in the United States. The mode in Europe is 'never' (about one-third of respondents), while the mode in the US is 'several times a day' (28.98) with 'once a day' lagging closely behind (26.36).

In the United States religious diversity was endorsed right from the beginning. Herberg's thesis (1960) implies that collective religious identities have been one of the primary ways of structuring societal pluralism in American history. In his words, "almost from the beginning, the structure of American society pre-supposed diversity and substantial equality of religious associations” (page 27). The United States offers a "religious supermarket" (Leggewie, 2007, page 5) with a horizontal and egalitarian 
structure of religions and sects that cultivate their religious identity. The trust and peaceful competition between different religions and sects is guaranteed by the market structure of the religious landscape: believers are treated as consumers. Leggewie (2007) summarizes the main features of the American religious setting: (a) a strict division of State and Church, combined with the open presence of many religions in the public sphere; (b) the erosion of religious oligopoly in favor of a dispersed horizontal structure of religious communities; (c) more intensive practice of religiosity; (d) individualization of the practice of religion; and (e) opportunities for politicized religious lobbies in domestic and foreign policy (page 5). In the United States, religion, religious institutions and religious identities played a central role in the process of incorporating the old European immigrants into American society. As a result, religious identities tended to gain salience in the context of immigration to America rather than losing their influence. They have the same function today as well (Smith, 1978; Warner, 2000; Kurien, 2001; Casanova, 2006). Moreover, immigrants in America try to conform to American standards of religiosity and sometimes become more religious in their new country (the United States) than they were in their home land (Williams, 1988).

At the other side of the Atlantic, Western European countries are extremely secular societies (Greeley, 2004). ${ }^{13}$ The constant religious decline since the 1950 s is explained by the 'secularization paradigm' which claims that secularization is normal and progressive and the consequence of being a modern 'enlightened' European. In the words of Swatos and Christiano (1999): “...in the face of scientific rationality, religion's influence on all aspects of life - from personal habits to social institutions is in dramatic decline” (page 214). Moreover, Europe took a very different path of historical religious development. In Europe, the experience of bloody religious wars between rival faith communities with exclusive claim to truth, led to the recognition of the sole authority of the state as a political power. European societies tend to tolerate and respect individual religious freedom. However, they have difficulty in recognizing collective group identities and the legitimate role for religion in public

\footnotetext{
${ }^{13}$ Obviously there are differences between countries within Europe in term of shares of the secular populations. Cyprus and Poland are the most religious countries in Europe (in 2008), while at the other end the Scandinavian countries, the Czech Republic and Estoniaare the most secular countries (ISSP 2008 data based on frequencies of church attendance and prayer, not reported. Will be provided upon request)
} 
life. $^{14}$ In light of the limited religious pluralism and drastic secularization, immigrants' religions (in particular Islam) and religiosity are treated with much suspicion by European elites and ordinary people alike.

(b) The composition of the immigration flow. In Europe, immigration and Islam are practically synonymous ${ }^{15}$ : the overwhelming majority of immigrants (in most European countries with the exception of the UK) are Moslems, and the overwhelming majority of Western European Moslems are immigrants. Figure 5 shows the percentages of Moslems in the country's population, distinguishing between natives and immigrants.

\section{Figure 5: Percentage of Moslems in the country's population - natives and} immigrants

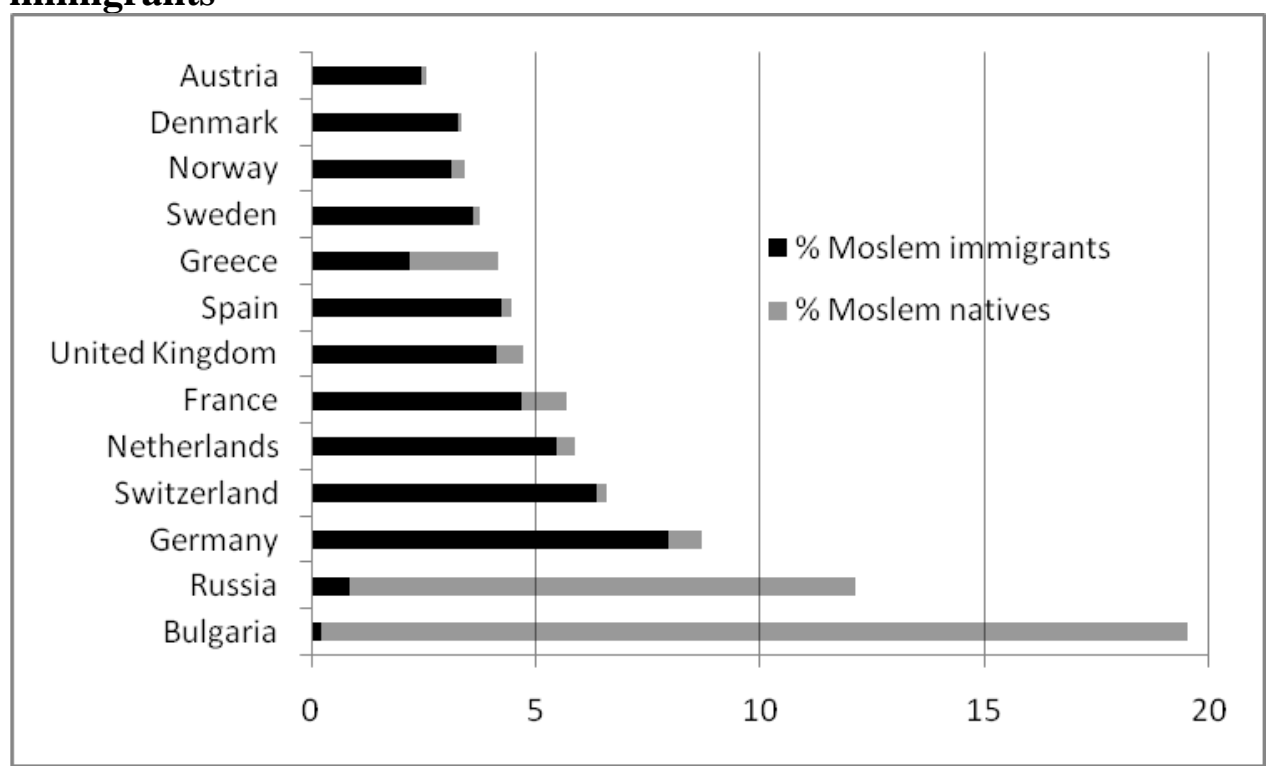

Source: ESS, waves 2002-2010

\footnotetext{
14 There are obviously differences between European countries in the regulation of religious minorities (Casanova, 2006): France's 'etatist' secularist model requires the strict privatization of religion, eliminating religion from any public forum. Great Britain allows greater freedom of religious associations and their contacts with local authorities. The Netherlands encouraged the establishment of a state-regulated but self-organized separate Moslem pillar. Germany has tried to organize a quasi-official Islamic institution (the Turkish-Islamic Union for Religious Affairs - DITIB), in conjunction with Turkey's Directorate of Religious Affairs (DRA) see Ogelman (2003). There are, however, other Moslem organizations who claim to represent the German Moslem population (Leggewie, 2007).

${ }^{15}$ Moslem populations have lived in the Balkans and Eastern Europe for centuries. There has also been a Moslem presence in Western Europe. However, the large Moslem populations that today live in Western Europe arrived after World War II (Fetzer and Soper, 2005). The authors analyze variations in the British, German and French state responses to Moslem religious demands in three areas of public policy: the accommodation of religious practices and teaching in public schools, the provision of state funding for Islamic schools, and regulations regarding the building of mosques.
} 
The similarity between immigrant status and the religion of Islam is even more pronounced in those countries where Moslem immigrants come predominantly from a single region of origin. Examples are Turkey in the case of Germany, and North Africa in the case of France. In this case, there is an overlap between immigration status, religion, and racial and socio-demographic background. This overlap magnifies the extent of 'otherness'. Moslem-organized collective identities and their public representations became a source of anxiety, not only because of their religious 'otherness' as non-Christians and practicing a non-European religion, but more importantly because of their religiousness itself in contrast to the European secularity. Moreover, there is some evidence that the religiosity of Moslem immigrants does not change as the time since migration goes by. Bisin et al. (2008) found that, in the United Kingdom, the religiosity of a Moslem born in the UK and having spent there more than 30 years, is comparable with that of a non-Moslemwho just arrived in the country (religiosity was proxied using data from a question on 'strong religious identity'). In the United States, by contrast, Moslems comprise no more than $10 \%$ of all new immigrants. ${ }^{16}$ Moreover, it is estimated that $30 \%-42 \%$ of all Moslems in the United States are African-American converts to Islam, complicating the definition of Islam as a foreign/non-American religion. Also, the Moslem immigrant communities in the United States are from diverse geographical regions of origin, as well as from varied socio-demographic backgrounds. All of the above lead to faster assimilation into the native population (Casanova, 2006). ${ }^{17}$ More generally: in the United States there is more similarity between the religious denominations of the immigrants and the host society, compared to Europe. In Europe, a significant share of immigrants are Moslems who live in a predominantly Christian society. Religion probably serves as a 'bridge' when the denominations are similar and as a 'buffer' if they differ.

These differences between Europe and the United States lead to the second hypothesis: Hypothesis 2: religiosity of immigrants in the United States has a more pronounced'bridging' nature, while in Europe, the religiosity of immigrants functions

\footnotetext{
${ }^{16}$ There are no reliable estimates on the number of Moslems in the United States, since the US Census Bureau, the Immigration and Naturalization Service, and other government agencies are not allowed to collect information on religion.

${ }^{17}$ This however did not prevent expressions of hostility and discrimination against Moslems after the 9/11 attacks. For instance Davila and Mora (2005) and Kaushal, Kaestner and Reimers (2007) found that subsequent to the attacks, middle-Eastern Arabs have experienced a significant decline in earnings.
} 
mainly as a 'buffer' element against conflict with the native population and serves as 'bonding capital' that helps the immigrants within their immigrant community. Therefore, in Europe the 'group threat theory' is expected to dominate in contrast to a more dominant 'intergroup contact theory' in the United States.

\section{Empirical analysis - descriptive figures and religiosity equations}

We use the European Social Survey (ESS, waves 2002-2010) and the American General Social Survey (GSS, waves 2002-2010) data sets to test the two hypotheses stated above: ( i) more pronounced religiosity of immigrants (in the United States and Europe); and (ii) dominance of the 'bridging factor' in the United States and of the 'buffer-bonding factor' in Europe - and consequently the dominance of the'intergroup contact theory'in the United States versus the 'group threat theory' that will be dominant in Europe.

The GSS and the ESS are social surveys designed in the United States and in Europe, respectively, to obtain the demographic, behavioral and cultural characteristics of their residents. The GSS has been conducted annually since 1972, and the last available wave is 2010. The ESS has 5 waves since 2002 (the first in 2002/2003 and the fifth in 2010/2011). The two surveys include questions on individuals' religious denomination and on other various measures of religiosity, and allow the distinction between natives and first- and second-generation immigrants.

The two samples (for the United States and for Europe) include pooled waves for the period 2002-2010. They are restricted to individuals in the age interval of 20-90 years, who belong to the following religious denominations: Catholic, Protestant, Orthodox, Jewish, Moslem, other Christian religions, and No-religion. Respondents belonging to other religions have been omitted from the analysis, due to the small sample sizes of these groups.The GSS allows the distinction between different sub-categories of Protestants. Using the classification system developed by Steensland et al. (2000) we distinguish between black-, evangelical-, and mainline-Protestants. Unfortunately, this distinction is not available in the ESS.

In the European sample, individuals were sampled within the following countries: Austria, Belgium, Bulgaria, Cyprus, the Czech Republic, Denmark, Estonia, Finland, France, Germany, Greece, Hungary, Ireland, Italy, Luxembourg, the Netherlands, Norway, Poland,Portugal, Russia, Spain, Sweden, Slovakia, Slovenia, Switzerland, Ukraine and the United Kingdom. 
Descriptive statistics for both samples (ESS-Europe and GSS-US) can be found in the Appendix in Table A.1 and A.2, respectively.

As a first approximation of measures of religiosity of (a) first-generation immigrants; (b) the native populations in the receiving countries; and (c) the populations in the sending-countries, the European Social Survey (ESS, waves of 2002-2010) is used for the calculation of the shares of religious individuals (measured by attendance of church services at least once a week). Table 3 presents several examples where the ESS data provides samples of at least 100 individuals. Unfortunately, the American comparable General Social Survey (GSS, waves 2002-2010) has only very small sample sizes to allow for a similar comparison.

It should be noted that Table 3 is based on raw figures, not controlled for differences in socio-economic characteristics that might affect religious behavior. Regression analysis will provide the more accurate measures. However, a regression analysis reported below does not include the shares of religious individuals in the sending-countries, because the ESS does not have data on religiosity of the populations in immigrants' origin-countries for those origincountries that are not included in the ESS survey. Formal country statistics on shares of religious individuals are not available either. 
Table 3: Percentages of religious individuals (attending religious church services at least once a week)

\begin{tabular}{lccc}
\hline Sending-country $\rightarrow$ Receiving- & $\begin{array}{c}\text { First gen. } \\
\text { immigrants in } \\
\text { receiving- } \\
\text { country }\end{array}$ & $\begin{array}{c}\text { Natives in } \\
\text { receiving- } \\
\text { country }\end{array}$ & $\begin{array}{c}\text { Population in } \\
\text { sending- } \\
\text { country }\end{array}$ \\
\hline Turkey $\rightarrow$ Germany (123) & $31.71 \%$ & $7.25 \%$ & $34.69 \%$ \\
Ukraine $\rightarrow$ Estonia (128) & $7.03 \%$ & $2.45 \%$ & $13.77 \%$ \\
Russia $\rightarrow$ Estonia (790) & $5.19 \%$ & $2.45 \%$ & $5.31 \%$ \\
Russia $\rightarrow$ Ukraine (376) & $6.38 \%$ & $14.42 \%$ & $5.31 \%$ \\
Russia $\rightarrow$ Germany (140) & $12.86 \%$ & $7.25 \%$ & $5.31 \%$ \\
Italy $\rightarrow$ Switzerland (151) & $15.23 \%$ & $10.88 \%$ & $31.12 \%$ \\
United Kingdom $\rightarrow$ Ireland (115) & $19.13 \%$ & $53.01 \%$ & $12.66 \%$ \\
Finland $\rightarrow$ Sweden (157) & $6.37 \%$ & $3.93 \%$ & $5.43 \%$ \\
\hline Source: ESS, waves 2002-2010. & & & \\
\hline
\end{tabular}

Source: ESS, waves 2002-2010.

Notes: In parentheses, number of first generation immigrants in receiving-country Included are sample sizes of at least 100.

As Table 3 indicates: In 6 out of the 8 examined cases, the first-generation immigrants are indeed more religious than the native population in the host-country (exceptions are: Russian immigrants in Ukraine, and UK immigrants in Ireland). The most notable case relates to Turkish immigrants in Germany: about one-third of them report that they attend religious services at a place of worship (mosque) at least once a week, compared to about $7 \%$ of the native German population. Williams' (1988) proposition that immigrants are also more religious in the receiving-country compared to the population in their country-of-origin is not supported by the European raw data: this is true only for Russian immigrants in Germany and marginally for Finnish immigrants to Sweden. Could be that Williams' proposition is relevant for the United States - for which we do not have the appropriate data for examination.

More refined regression analysis is now used (with the same data from the 2002-2010 waves of the European ESS and the American GSS), to test if immigrants (first- and secondgeneration) are more religious than the native respective populations, in Europe and in the United States. 
Table 4 presents regression equations for two elements of religiosity: (i) Attendance to religious services at the place of worship ('church attendance', based on the question: "How often do you attend religious services?", ranging from 'never' to 'every day' on a scale of 1-7 in the ESS and a scale of 0-8 in the GSS); and (ii) prayer habits ('prayer', based on the question: "How often do you pray?", ranging from 'never' to 'every day', on a scale of 1-7 in the ESS and 1-6 in the GSS). Church attendance is a public religious activity that also includes elements of networking. Prayer has a private/intimate nature.

The equations for the two places include the same explanatory variables in order to facilitate a comparative analysis of the results. The two core variables are 'first-generation immigrants'dummy (=1if the respondent and his/her parents were not born in the current country of residence) and 'second-generation immigrants' dummy (=1 if the respondent was born in the current country of residence but both of his/her parents were born in other countries). The battery of other explanatory variables includes: age groups (younger than 31reference; 31-45; 46-59; 60 or older); education dummies (less than six years of education reference; 7-12; 13-16; more than 16 years); marital status (single - reference; married or cohabiting; divorced or separated; widowed); employment status (retired, at school or homekeeper - reference; employee; self-employed; unemployed); low income dummy (=1 if total family annual income is less than 6000 euros); number of people in household ${ }^{18}$; female dummy; and the religious denomination (Catholic - reference; Protestant; Orthodox; Other Christian denomination; Jewish; Moslem). Respondents who reported that they have 'No religion' are also included as one of the denominations due to the size and importance of this group. The European regressions include also country dummies; and all regressions include controls for the waves.

Linear Ordinary Least Squares regressions were used and standard errors were adjusted for clustering at the country level (in European regressions). Switching to Ordered Logit/Probit regressions did not lead to substantial changes. This simpler OLS method allows for the inclusion of interaction terms and tests of their statistical significance in a much easier way (using t- and F-tests) than in Ordered (Probit/Logit) models (Norton et al., 2004). Population and design survey weights were also taken into account.

\footnotetext{
${ }^{18}$ We use this variable as a proxy of number of children, because the ESS does not include data on the number of children.
} 
Table 4: Attendance to religious services and prayer, Europe and the US (2002-2010)

\begin{tabular}{|c|c|c|c|c|}
\hline Variables & $\begin{array}{l}\text { Attendance to } \\
\text { religious } \\
\text { services } \\
\text { EUROPE }\end{array}$ & $\begin{array}{l}\text { Attendance to } \\
\text { religious } \\
\text { services } \\
\text { US }\end{array}$ & $\begin{array}{c}\text { Frequency of } \\
\text { prayer } \\
\text { EUROPE }\end{array}$ & $\begin{array}{c}\text { Frequency of } \\
\text { prayer } \\
\text { US }\end{array}$ \\
\hline \multicolumn{5}{|l|}{ Immigrant var. } \\
\hline First-generation & $0.206 * *$ & $0.236 * * *$ & $0.582 * * *$ & $-0.139 * *$ \\
\hline Second-generation & 0.114 & -0.078 & $0.281 * *$ & -0.067 \\
\hline \multicolumn{5}{|l|}{$\begin{array}{l}\text { Socio-economic vars. } \\
\text { Age (years) }\end{array}$} \\
\hline 30 and under & ref. & ref. & ref. & ref. \\
\hline 31 to 45 & $0.045^{* *}$ & 0.038 & $0.163 * * *$ & $0.207 * * *$ \\
\hline 46 to 59 & $0.100 * *$ & 0.078 & $0.321 * * *$ & $0.329 * * *$ \\
\hline 60 and over & $0.291 * * *$ & $0.522 * * *$ & $0.740 * * *$ & $0.285 * * *$ \\
\hline \multicolumn{5}{|l|}{$\begin{array}{l}\text { Education (years } \\
\text { completed) }\end{array}$} \\
\hline Less than 6 & ref. & ref. & ref. & ref. \\
\hline 7 to 12 & $-0.173 * * *$ & -0.072 & $-0.301 * * *$ & $-0.193 *$ \\
\hline 13 to 16 & $-0.145 * * *$ & $0.322 * *$ & $-0.327 * * *$ & -0.155 \\
\hline 17 and over & -0.094 & $0.681 * * *$ & $-0.252 * * *$ & -0.270 \\
\hline Female & $0.246^{* * *}$ & $0.480 * * *$ & $0.799 * * *$ & $0.738 * * *$ \\
\hline People in household & $0.056 * * *$ & $0.065 * * *$ & $0.059 * * *$ & 0.006 \\
\hline \multicolumn{5}{|l|}{ Marital status } \\
\hline Single & ref. & ref. & ref. & ref. \\
\hline Married & $0.102 * * *$ & $0.550 * * *$ & $0.099 * * *$ & $0.195 * * *$ \\
\hline Divorced & -0.043 & $-0.128 *$ & $0.101 * * *$ & $0.112 * *$ \\
\hline Widowed & $0.155^{* * *}$ & $0.490 * *$ & $0.486 * * *$ & $0.216^{* * *}$ \\
\hline Low income & -0.000 & -0.023 & $0.141 *$ & $0.185^{* * *}$ \\
\hline \multicolumn{5}{|l|}{ Employment status } \\
\hline Retired/student/home & ref. & ref. & ref. & ref. \\
\hline Employee & $-0.190 * *$ & 0.028 & $-0.195 * * *$ & $-0.136 * * *$ \\
\hline Self-employed & $-0.141^{* *}$ & -0.048 & -0.097 & -0.047 \\
\hline Unemployed & $-0.080 * * *$ & $-0.296 * *$ & -0.049 & -0.090 \\
\hline \multicolumn{5}{|l|}{ Religion var. } \\
\hline Catholic & ref. & ref. & ref. & ref. \\
\hline Protestant: & $-0.305^{* *}$ & & $-0.383 *$ & \\
\hline Black & & $-0.244 * * *$ & & 0.053 \\
\hline Evangelical & & $0.663^{* * *}$ & & $0.354 * * *$ \\
\hline Mainline & & $-0.472 * * *$ & & $-0.283 * * *$ \\
\hline Orthodox & $-0.450 * * *$ & $-0.692 * *$ & $-0.370 * *$ & $-0.487 *$ \\
\hline Other Christian & $0.721^{* * *}$ & 0.017 & $1.030 * * *$ & $0.319 * * *$ \\
\hline Jewish & $-0.418 * * *$ & $-1.607 * * *$ & -0.374 & $-1.246^{* * *}$ \\
\hline Moslem & -0.176 & 0.264 & $0.363^{*}$ & $0.678 * *$ \\
\hline No religion & $-1.537 * * *$ & $-3.028 * * *$ & $-2.300 * * *$ & $-1.714^{* * *}$ \\
\hline Country dummies & yes & - & yes & - \\
\hline Wave dummies & yes & yes & yes & yes \\
\hline Sample Size & 182,101 & 11,440 & 179,707 & 7,869 \\
\hline R-squared & 0.396 & 0.245 & 0.397 & 0.272 \\
\hline
\end{tabular}

${ }^{*}$ p-value $<0.10 ; * *$ p-value $<0.05 ;{ }^{* * *}$ p-value $<0.01$ 
Hypothesis 1, which states that Immigrants are more religious than the native population, is clearly supported by the European data:the coefficients of first-generation European immigrants are positive and significant for the two dimensions of religiosity, indicating that first-generation immigrants in Europe are indeed more religious than the native population (the reference group). The size of the coefficient in prayer equation drops when secondgeneration immigrants are considered, but the coefficient is still significant. In the United States the results are weaker: first-generation immigrants seem to be more religious in terms of church attendance, but less religious in terms of prayer (indicating a bridging factor of religiosity - see below).

The socio-economic and religious denomination variables serve as control variables. Most coefficient estimates are quite similar in Europe and in the United States and are in line with the findings of many other studies:women are more religious than men; single individuals tend to be less religious compared to married and widowed; number of people in household has a positive significant effect on religiosity; low income increases prayer; unemployed individuals attend church services less frequently; advanced age leads to more intensive religiosity (in particular above the age of 60); and there is some tendency toward decreased religiosity when the individual is more educated. One interesting exception is the increase in church attendance of US respondents with more than 13 years of education. These respondents attend church activities more frequently than individuals with less than graduate education, probably because they benefit more from networking and contact effects. An obvious result is the much less intensive religious activity of respondents who claim to have 'No religion'.

We now turn to the second hypothesis.Hypothesis 2: In European countries the 'bufferbonding motive' is dominant, whereas in the United States the 'bridging motive' is more powerful.

It is obviously impossible to disentangle the two motives and offer an estimate of their sizes. However, the results in Table 4 provide several clear indications in support of this hypothesis.

1. In the United States first-generation immigrants attend church religious services more frequently than the native population. However, first-generation immigrants pray less compared to natives. Attendance to church services has a clear networking and bridging element (and might also have a bonding element). Prayer has no bridging component and 
can only serve as a 'buffer' and "balm to the soul". More frequent attendance to church services (compared to natives), coupled with less prayer habits, can therefore point towards the dominance of the bridging component. In sharp contrast, immigrants in the European countries are more active in terms of prayer. The intensity drops in the second generation, but is still significantly higher compared to natives. These results can be explained by the need for comfort and a "balm for the soul" that does not fade away in the second generation.

2. The coefficients that present the more intensive religiosity of immigrants in Europe are much larger in the 'prayer equation' than in the 'church attendance equation' (both use the same 1-7 scale). Prayer has the intimate/private nature of comforting and providing a "balm to the soul". It can serve as a 'buffer' and shield against the harsh conditions faced by new immigrants. The larger magnitude of the prayer coefficients in Europe can therefore serve as another indication of the superiority of the 'bonding-buffer' motive. ${ }^{19}$

3. Although we focus on the religiosity of immigrants, religious activity can be a 'buffer' also for natives who face religious discrimination or harsh religious conditions. Individuals who have a religious denomination that is different from the main country's denomination, may be subject to religious unease or discrimination in European countries that do not have a culture of religious diversity and tolerance. Such individuals will then turn to intensive religiosity to find comfort. In the United States, which enjoys a "religious supermarket" and tolerates a diversity of religions, belonging to a religion that is different from the country's major religion does not lead to discriminatory feelings, but could lead to a diminished magnitude of the networking/bridging element (which is also relevant for natives). To test these country differences, we add the dummy variable 'not belonging to the country's main religion' ( $=1$ if the respondent's religious denomination is different from the main religion in the country) and its interactions with first- and secondgeneration immigrant dummies to the regression in Table 4. To study the significance of an interaction it is necessary to test the joint hypothesis that both coefficients are zero using the F-test and not the separate t-statistics (Wooldridge, 2003). We include the F-

\footnotetext{
19 There could, however, be other explanations as well. For instance, (i) church attendance is more costly (in terms of time and also financial expenditures) and it is therefore cheaper to intensify prayer habits; (ii) in Islam praying several times a day is more of an indicator of intensive religiosity than in Christianity: As immigrants to Europe, but not to the US are overwhelmingly Moslem, we find a stronger effect of the immigration status on prayer in Europe (see also Hill and Pargament, 2003, on different manifestations of religiosity within Christian vs. non-Christian populations).
} 
statistics of the interactions in the two regressions and indicate (using asterisks) if the null hypothesis that 'both coefficients are zero' is rejected.

Table 5: Attendance to religious services and prayer, Europe and the US (2002-2010), adding the 'not main religion' variable

\begin{tabular}{|c|c|c|c|c|}
\hline Variables & $\begin{array}{c}\text { Attendance to } \\
\text { religious } \\
\text { services } \\
\text { EUROPE } \\
\end{array}$ & $\begin{array}{c}\text { Attendance to } \\
\text { religious } \\
\text { services } \\
\text { US } \\
\end{array}$ & $\begin{array}{c}\text { Frequency of } \\
\text { prayer } \\
\text { EUROPE } \\
\end{array}$ & $\begin{array}{c}\text { Frequency of } \\
\text { prayer } \\
\text { US } \\
\end{array}$ \\
\hline \multicolumn{5}{|l|}{ Immigrant var. } \\
\hline First-generation & $0.146 *$ & $0.595^{* * *}$ & $0.497^{* *}$ & -0.017 \\
\hline Second-generation & -0.063 & 0.164 & $0.217 * *$ & 0.046 \\
\hline Not main religion & $0.515 * * *$ & $-0.678 * * *$ & $1.025 * * *$ & $-0.465^{* * *}$ \\
\hline \multicolumn{5}{|l|}{ Interactions } \\
\hline First-gen.*Not main rel. & 0.046 & $-0.409 * * *$ & 0.025 & -0.131 \\
\hline Sec-gen.*Not main rel. & $0.253 * * *$ & -0.280 & 0.032 & -0.131 \\
\hline Socio-economic vars. & yes & yes & yes & yes \\
\hline $\begin{array}{l}\text { Religious denomination } \\
\text { variables }\end{array}$ & yes & $\mathrm{no}^{20}$ & yes & no \\
\hline Country dummies & yes & - & yes & - \\
\hline Wave dummies & yes & yes & yes & yes \\
\hline \multicolumn{5}{|l|}{$\begin{array}{l}\text { Interaction significance } \\
\text { (F-statistics) }\end{array}$} \\
\hline First-gen.*Not main rel. & $2.86^{*}$ & $7.53^{* * *}$ & $7.58^{* * *}$ & 2.10 \\
\hline Sec-gen.*Not main rel. & $4.06 * *$ & 0.51 & $3.75^{* *}$ & 0.39 \\
\hline Sample Size & 182,101 & 11,440 & 179,707 & 7,869 \\
\hline R-squared & 0.400 & 0.236 & 0.403 & 0.259 \\
\hline
\end{tabular}

${ }^{*} \mathrm{p}$-value $<0.10 ; * *$ p-value $<0.05 ; * * *$ p-value $<0.01$

As is indicated by Table 5, in Europe, individuals who do not belong to the country's major religion are indeed significantly more religious, and religiosity is further intensified if they are immigrants. Most probably, they find in the religious activities a 'buffer' against being outsiders in terms of religion. This adds more evidence to the 'bonding-buffer' nature of religion in Europe.

In the United States: Natives who do not belong to the country's main religion are less religious - in terms of church-attendance and also in terms of prayer - compared to natives who share the main religion. First-generation immigrants further decrease their church-attendance compared to American natives. The negative coefficient for 'church-

\footnotetext{
${ }^{20}$ In the American equation, the dummies for religious denomination are excluded to avoid multicollinearity with 'does not belong to the main (Evangelical-Protestant) religion'. The results are therefore not fully comparable.
} 
attendance' can be explained a diminished networking and bridging incentive. Prayer however does not have a networking/bridging element. Here the result can be explained by inconformity: if an individual is different in terms of her/his religious denomination, she/he is also different in the sense that she/he is less religious compared to the 'average' religious American.

4. 'Bridging' and 'bonding' motives of immigrants' religiosity are expected to become weaker as the immigrant becomes more integrated into the local society. It is therefore expected that the effects will diminish with time since immigration. The European data provides information on time since immigration. To study the effect of duration of residence in the country, on the religiosity of first-generation immigrants, we added interactions of 'firstgeneration immigrants' with 'duration of residence in the host country' (time intervals of 6-10 years; $11-20$ years; and more than 20 years, with $0-5$ as the reference group) to the European models presented in Table 4. Although we do not have the comparative aspect (Europe versus the United States), because the data for the United States does not include the 'duration' variable, the extended equations provide additional indications of the dominance of the 'buffer-bonding factor' in the European countries. 
Table 6: Attendance to religious services and prayer in Europe, 2002-2010, adding 'duration since immigration' variables

\begin{tabular}{|c|c|c|}
\hline Variables & $\begin{array}{c}\text { Attendance to religious } \\
\text { services } \\
\text { EUROPE } \\
\end{array}$ & $\begin{array}{l}\text { Frequency of } \\
\text { prayer } \\
\text { EUROPE } \\
\end{array}$ \\
\hline \multicolumn{3}{|l|}{ Immigrant var. } \\
\hline First-generation & $0.222 * * *$ & $0.678 * * *$ \\
\hline Second-generation & 0.098 & $0.236 * *$ \\
\hline \multicolumn{3}{|l|}{ Residence duration } \\
\hline (6-10)*First-gen. & -0.018 & 0.102 \\
\hline$(11-20)^{*}$ First-gen. & -0.075 & -0.208 \\
\hline (20 and over)*First-gen & -0.070 & $-0.298 * *$ \\
\hline Socio-economic vars. & yes & yes \\
\hline Religion variables & yes & yes \\
\hline Country dummies & yes & yes \\
\hline Wave dummies & yes & yes \\
\hline \multicolumn{3}{|l|}{$\begin{array}{l}\text { Interaction significance } \\
\text { (F-statistics) }\end{array}$} \\
\hline$(6-10) *$ First-gen. & $7.42 * * *$ & $17.61^{* * *}$ \\
\hline (11-20)*First-gen. & $5.56 * * *$ & $13.70 * * *$ \\
\hline (20 and over)*First-gen & $6.04 * * *$ & $16.47 * * *$ \\
\hline Sample Size & 182,101 & 179,707 \\
\hline R-squared & 0.399 & 0.403 \\
\hline
\end{tabular}

As Table 6 indicates, the intensified religiosity of first-generation immigrants indeed diminishes significantly with the increase in duration in the host country (all interactions are significant).Van Tubergen and Sindradóttir (2011) also find that religiosity is higher among immigrants who have recently arrived in the host country. The interesting finding, that might lend further support to the dominance of the 'bonding-buffer' motive in Europe, is that the decrease in prayer is much more pronounced than the decrease in church attendance. While church attendance could also have a networking/bridging element, prayer has a pure 'bonding-buffer' element. It is plausible that as immigrants become more integrated they need less "balm to the soul".

5. Another indirect indicator of the dominance of the 'bridging' versus the 'bonding-buffer' effects could be gained from an insightful reading of the results of an experimental test of the 'intergroup contact theory' versus the 'group threat theory'. As mentioned above, the' intergroup contact theory' predicts that an increase in the relative size of a (religious) minority provides contact opportunities with the minority and leads to less discrimination. This is the case if religiosity serves as a bridging element. The 'group threat theory' 
predicts that an increase in the relative size of a minority leads to an augmented threat to the native population and therefore to intensified hostility. This could be the case if religiosity serves as a bonding element within the minority/immigrant community and a buffer against the native community. Connecting to Adida, Laitin and Valfort (2011) who

found support for the threat theory (towards the Moslem religious minority), it can be claimed that their findings also lend support to the dominance of the 'buffer-bonding' motive rather than the 'bridging' motive. The experiment was conducted in France only and there is no comparable experiment for the United States. However, it offers some additional evidence in the same line.

\section{Concluding remarks}

Immigration and the religiosity of immigrants are key factors in shaping the religious and demographic landscape of Europe and the United States. The evolution and the impacts of the immigration-religiosity intersections are fundamentally different on the two sides of the Atlantic: in the United States religiosity seems to serve as a 'bridge', helping immigrants in the integration process. In Europe, intensified religiosity of immigrants seems to serve more like a 'buffer' and shock-absorber, offering comfort and shield against the hardships that newcomers face. These fundamental differences are the result the different religious cultures and religious landscapes of the two regions, and also the different mix of immigration flows. In particular, American religious pluralism allows immigrants to choose between creating their own religious communities versus joining local religious organizations. In any case, religious activity provides refuge, security, and various services and resources (employment, housing, education), and creates linkages between the immigrants and the native population, thus smoothening the integration process. The situation in Europe is totally different: religious pluralism in Europe is limited. Moreover, the European society tends to tolerate and respect individual religious freedom, but has difficulty in recognizing collective group religiosity and the legitimate role for religion in public life. Combined with the restricted religious pluralism, and drastic European secularization, immigrants' religions (in particular Islam) and religiosity are treated with much suspicion by European elites and ordinary people alike. In Europe the 'group threat theory' seems to govern, and the increase in the size of religious minorities generates hostile attitudes by the dominant native population toward the 
religious minority. The predicted growing share of Moslem immigrants in European countries will potentially become a source of deep social and religious tensions. Solutions to discrimination against Moslems are therefore of urgent concern. However, as Paluck and Green (2009) show, evidence on prejudice-reducing policies is at best inconclusive.

The 'good news' is that there might be hope for better integration of the immigrant population in Europe as time goes by. This is indicated by the following circumstantial evidence: (i) as Table 6 indicates, intensified religiosity of immigrants has a tendency to decline over time as second-generation immigrants are less religious than first-generation immigrants, and even the religiosity of first-generation immigrants decreases with the years since migration. Aleksynska and Chiswick (2011) arrive at a similar result. This decline suggests that a certain adaptation to the religious environment in the host country is taking place; (ii) more evidence that the religiosity of immigrants is not an absolutely rigid personal trait is provided by Aleksynska and Chiswick (2011), who show that while the characteristics of the origin countries (i.e., religious pluralism, religious freedom, and social attitudes toward religion) determine immigrants' religiosity even after migration, the impact of these factors is much weaker compared to the host countries' characteristics. It therefore follows that religiosity does change and adapt to local host country factors; and (iii) Dustmann and Frattini (2011) investigated the assimilation of new immigrants into the local labor market, which also reflects other types of assimilation and adaptation. They present figures that clearly illustrate that longer exposure to immigration has a positive effect on labor market assimilation of recent non-EU immigrants (but does not affect EU immigrants). A country indicator of the 'length of exposure to foreign-born individuals' is defined by the 'share of foreign born in 2010 over the share of foreign born in 1960'. The index of occupational dissimilarity between recent immigrants and natives and the gap in employment probability between immigrants and native are plotted (each separately) against the index of 'exposure to foreign-born individuals'. The figures demonstrate that both occupational dissimilarity and employment gaps are larger for countries where the 'exposure index' is larger. In other words, longer exposure to immigration (indicated by a lower share of foreign born in 2010 to foreign born in 1960) leads to better assimilation of newcomers into the local labor market. It follows that longer exposure and contact with immigrants who arrived in the country 50 years ago results in better employment prospects for new immigrants. A relatively larger share of 'old immigrants' leads to the better assimilation of recent immigrants. The authors also claim that 
institutions and labor regulations play a role in immigrants' labor-market assimilation: recent immigrants in countries with stricter employment protection exhibit an occupational distribution that is more distinct from that of natives. It follows that relaxing labor regulations can lead to better immigrant assimilation.

To conclude, religiosity could serve as a tool for the integration of immigrants on the two sides of the Atlantic. Although this 'tool' currently seems to be less effective in Europe than in the United States, adaptation to the religious environment in the host country would take place as time goes by, allowing bridges to be built between immigrants and the local native population.

\section{References}

Adida, C.L., Laitin, D.D. and M.A. Valfort (2011), “’One Muslim is Enough!” Evidence from a Field Experiment in France', IZA Discussion Paper No. 6122. Bonn.

Aleksynska, M. and B.R. Chiswick (2011), 'Religiosity and Migration: Travel into One’s Self versus Travel across Cultures', IZA Discussion Paper No. 5724. Bonn.

Allen, C. and Nielsen, J.S. (2002), 'Summary Report on Islamophobia in the EU after 11 September 2001', Vienna: European Monitoring Center on Racism and Xenophobia.

Allport, G. (1954), The Nature of Prejudice, New York: Doubleday.

Bar-El, R., Garcia-Muñoz, T., Neuman, S. and Y. Tobol (2012), 'The Evolution of Secularization: Cultural Transmission, Religion and Fertility- Theory, Simulations and Evidence', Journal of Population Economics, forthcoming.

Bisin, A. and T. Verdier (2000), 'Beyond the Melting Pot: Cultural Transmission, Marriage, and he Evolution of Ethnic and Religious Traits', The Quarterly Journal of Economics,115(3), 955-988.

Bisin, A. and T. Verdier (2001), 'The Economics of Cultural Transmission and the Dynamics of Preferences', Journal of Economic Theory,97, 298-319. 
Bisin, A., Patacchini, E., Verdier, T. and Y. Zenou (2008), 'Are Islam Immigrants Different in Terms of Cultural Integration?', Journal of the European Economic Association,6(2-3), 445-456.

Blalock, H.M. (1967), Towards a Theory of Minority-Group Relations, New York: Capricorn Books.

Borjas, G.J. and L. Hilton (1996), 'Immigration and the Welfare State: Immigrant Participation in Means-Tested Entitlement Programs', Quarterly Journal of Economics, 111, 575-604.

Brañas-Garza, P. and S. Neuman (2004), 'Analyzing Religiosity within an Economic Framework: The Case of Spanish Catholics', Review of Economics of the Household, 2 (1), 5-22.

Cadge, W. and E.H. Ecklund (2006), 'Religious Service Attendance among Immigrants: Evidence from the New Immigrant Survey-Pilot', American Behavioral Scientist, 49 (11): 1574-1595.

Casanova, J. (1994), Public Religions in the Modern World, Chicago: University of Chicago Press.

Casanova, J. (2006), 'Religion, European Secular Identities, and European Integration', in Religion in an Expanding Europe, Cambridge: Cambridge University Press, pp. 65-92.

Chiswick, C.U. (2003), 'Immigrant Religious Adjustment: An Economic Approach to Jewish Migrations', IZA Discussion Paper No. 863. Bonn.

Connor, P. (2010), 'Balm for the Soul: Immigrant Religion and Emotional Well-Being', International Migration, DOI: 10.1111/j.1468-2435.2010.00623.x.

Constant A., Gataullina, L. Zimmermann, K.F. and L. Zimmermann (2006), 'Clash of Cultures: Muslims and Christians in the Ethnosizing Process', IZA Discussion Paper No. 2350. Bonn. 
Cyrus, N., Gropas, R. and A. Kosic (2006), ’”Opportunity Structures for Immigrants” Active Civic Participation in the European Union: Sharing Comparative Observations', POPITIS Working Paper No. 2. Oldenburg: University of Oldenburg.

Davila, A. and M.T. Mora (2005), Changes in the Earnings of Arab Men in the US between 2002 and 2002', Journal of Population Economics,18 (4), 587-601.

Dustmann, C. and T. Frattini (2011), 'Immigration: The European Experience', IZA Discussion Paper No. 6261. Bonn

Ebaugh, H.R. and J.S. Chafetz (1999), 'Agents for Cultural Reproduction and Structural Change: The Ironic Role of Women in Immigrant Religious Institutions', Social Forces,78 (2), 585-612.

Ebaugh, H.R. and J.S. Chafetz (2000), Religion and the New Immigrants: Continuities and Adaptations in Immigrant Congregations, Walnut Creek, CA: AltaMira Press.

Fetzer, J.S. and J.C. Soper (2003), 'The Roots of Public Attitudes toward State Accommodation of European Moslems' Religious Practices before and after September $11^{\text {th }}$,Journal for the ScientificStudy of Religion, 42 (2), 247-258.

Fetzer, J.S. and J.C. Soper (2005),Islam and the State in Britain, France, and Germany, Cambridge: Cambridge University Press.

Ghazal-Read, J. (2004), ‘Cultural Influences on Immigrant Women’s Labor Force Participation: The Arab-American Case’, International Migration Review, 38(1), 52-77.

Gordon, M.M. (1964), Assimilation in American Life, New York: Oxford University Press.

Goujon, A., Skirbekk, V., Fliegenschnee, K. and P. Strzelecki (2006), 'New Times, Old Beliefs: Projecting the Future Size of Religions in Austria', Working Paper 01/2006. Vienna Institute of Demography.

Greeley, A.M. (1972), The Denominational Society: A Sociological Approach to Religion in America, Glenview, IL: Scott, Foresman. 
Greeley, A.M. (2004), Religion in Europe at the End of the Second Millennium: a Sociological Profile, New Jersey: Transaction Publishers.

Herberg, W. (1960), Protestant, Catholic, Jew: An Essay on American Religious Sociology, Garden City, NY: Anchor.

Hill, P.C. and K.I. Pargament (2003), 'Advances in the Conceptualization and Measurement of Religion and Spirituality: Implications for Physical and Mental Health Research', American Psychologist, 58 (1), 64-74.

Ingelhart, R. and P. Norris (2004), Sacred and Secular: Religion and Politics Worldwide, Cambridge: Cambridge University Press.

Kaufmann, E. (2010), Shall the Religious Inherit the Earth?, Profile Books LTD.

Kaushal, N., Kaestner, R. and R. Reimers (2007), 'Labor Market Effects of September 11th on Arab and Muslim Residents in the United States',Journal of Human Resources,32(1), 182209.

Kurien, P. (2001), 'Religion, Ethnicity and Politics: Hindu and Islam Indian Immigrants in the United States', Ethnic and Racial Studies,24(2), 263-293.

Leggewie, C. (2007), 'Between National Church and Religious Supermarket', Eurozine Review (at: www.eurozine.com).

Lehrer, E.L. (2010), 'Religion, Human Capital Investments and the Family in the United States', in: McCleary R. (ed.), The Oxford Handbook of the Economics of Religion, New York: Oxford University Press.

Lesthaeghe, R.J. and L. Neidert (2006), 'The Second Demographic Transition in the United States: Exception or Textbook Example?', Population and Development Review, 32(4), 669698.

Lozano, F.A. and M.D. Steinberger (2010), 'Empirical Methods in the Economics of International Migration', IZA Discussion Paper No. 5328. Bonn. 
Mayda, A.M. (2010), 'International Migration: A Panel Data Analysis of the Determinants of Bilateral Flows', Journal of Population Economics,23, 1249-1274.

Munshi, K. (2003), 'Networks in the Modern economy: Mexican Migrants in the U.S. Labor Market', Quarterly Journal of Economics,118,549-597.

Neuman, S. (2005), 'Aliya to Israel: Immigration under Conditions of Adversity', in: Zimmermann K.F. (ed.) European Migration: What Do We Know?, Oxford University Press, pp. 459-506.

Norton E.C., Wang H. and C. Ai C (2004), 'Computing Interaction Effects and Standard Errors in Logit and Probit Models', The Stata Journal,4 (2), 154-167.

Ogelman, N. (2003), 'Documenting and Explaining the Persistence of Homeland Politics among Germany’s Turks’, International Migration Review,37, 163-193.

Ozyurt, S.S. (2009), 'Living Islam in Non-Islam Spaces: How Religiosity of Islam Immigrant Women Affect their Cultural and Civic Integration in Western Host Societies'.The Center for Comparative Immigration Studies, Working Paper No. 179, University of California, San Diego.

Paluk, E.L. and D.P. Green (2009), 'Prejudice Reduction: What works? A Critical Look at Evidence from the Field and the Laboratory', Annual Review of Psychology, 60, 339-367.

Peek, L. (2005), 'Becoming Islam: The Development of a Religious Identity', Sociology of Religion, 66 (3), 215-242.

Pew Research Center Report (2011), 'The Future of the Global Moslem Population: Projections for 2010-2030', Washington.

Putnam, R.D. (2000), Bowling Alone: The Collapse and Revival of American Community, New York: Simon and Schuster.

Putnam, R.D. and D.E. Campbell (2010), American Grace: How Religion Divides and Unites Us,New York: Simon and Schuster. 
Ramakrishnan, K and C. Viramontes (2006), Civic Inequalities: Immigrants Volunteerism and Community Organizations in California.Public Policy Institute of California.

Ruhn, M. and P. Martin (2008), 'Numbers versus Rights: Trade-offs and Guest Worker Programs’, International Migration Review,42, 249-265.

Sheridan L.P. and R. Gillett (2005), ‘Major World Events and Discrimination’, Asian Journal of Social Psychology,8 (2), 191-197.

Skirbekk, V., Goujon, A. and E. Kaufmann (2010), 'Secularism, Fundamentalism, or Catholicism? The Religious Composition of the United States in 2043', Journal for the Scientific Study of Religion,49 (2), 293-310.

Smith, T. (1978), 'Religion and Ethnicity in America', American Historical Review,83, 11551185.

Sommerville, C.J. (1998), 'Secular Society/Religious Population: Our Tacit Rules for Using the Term 'Secularization’’, Journal for the Scientific Study of Religion,37(2), 249-253.

Steensland, B., Park J.Z., Regneru, M.D., Robinson L.D., Wilcox W.B. and R.D. Woodberry (2000), 'The Measure of American Religion: Toward Improving the State of the Art', Social Forces, 79 (1), 291-318.

Strabac, Z. and O. Listhaug (2008), 'Anti-Muslin Prejudice in Europe: A Multilevel Analysis of Survey Data from 30 Countries’, Social Science Research37 (1), 268-286.

Swatos, W.H. and K.J.Christiano (1999), 'Secularization Theory: The Course of a Concept', Sociology of Religion, 60 (3), 209-228.

Tiilikainen, M. (2003), ‘Somali Women and Daily Islam in Diaspora’, Social Compass,50 (1), 59-69.

Toft, M.D., Philpott, D. and T.S. Shah (2011), God's Century: Resurgent Religion and Global Politics, W.W. Norton \& Company.

Tschannen, O. (1991), 'The Secularization Paradigm: A Systematization', Journal for the Scientific Study of Religion, 30, 395-415. 
Van Tubergen, F. And J.I.Sindradóttir (2011), 'The Religiosity of Immigrants in Europe: A Cross-National Study', Journal for the Scientific Study of Religion, 50 (2), 272-288.

Waite, L. and E.L. Lehrer (2003), 'The Benefits from Marriage and Religion in the United States: A Comparative Analysis', Population and Development Review,29 (2), 255-275.

Warner, R.S. (2000), 'Religion and the New (post-1965) Immigrants: Some Principles Drawn from Field Research’, American Studies,41, 267-286.

Weber, M. (1930), The Protestant Ethic and the Spirit of Capitalism, London, England: Allen and Unwin.

Williams, R.B. (1988). Religions of Immigrants from India and Pakistan: New Threads in American Tapestry, New York: Cambridge University Press.

Wooldridge, J.M (2003). Introductory Econometrics: A Modern Approach, ed. SouthWestern, $2^{\text {nd }}$ edition. 


\section{Appendix}

Table A.1. ESS-Europe: descriptive statistics

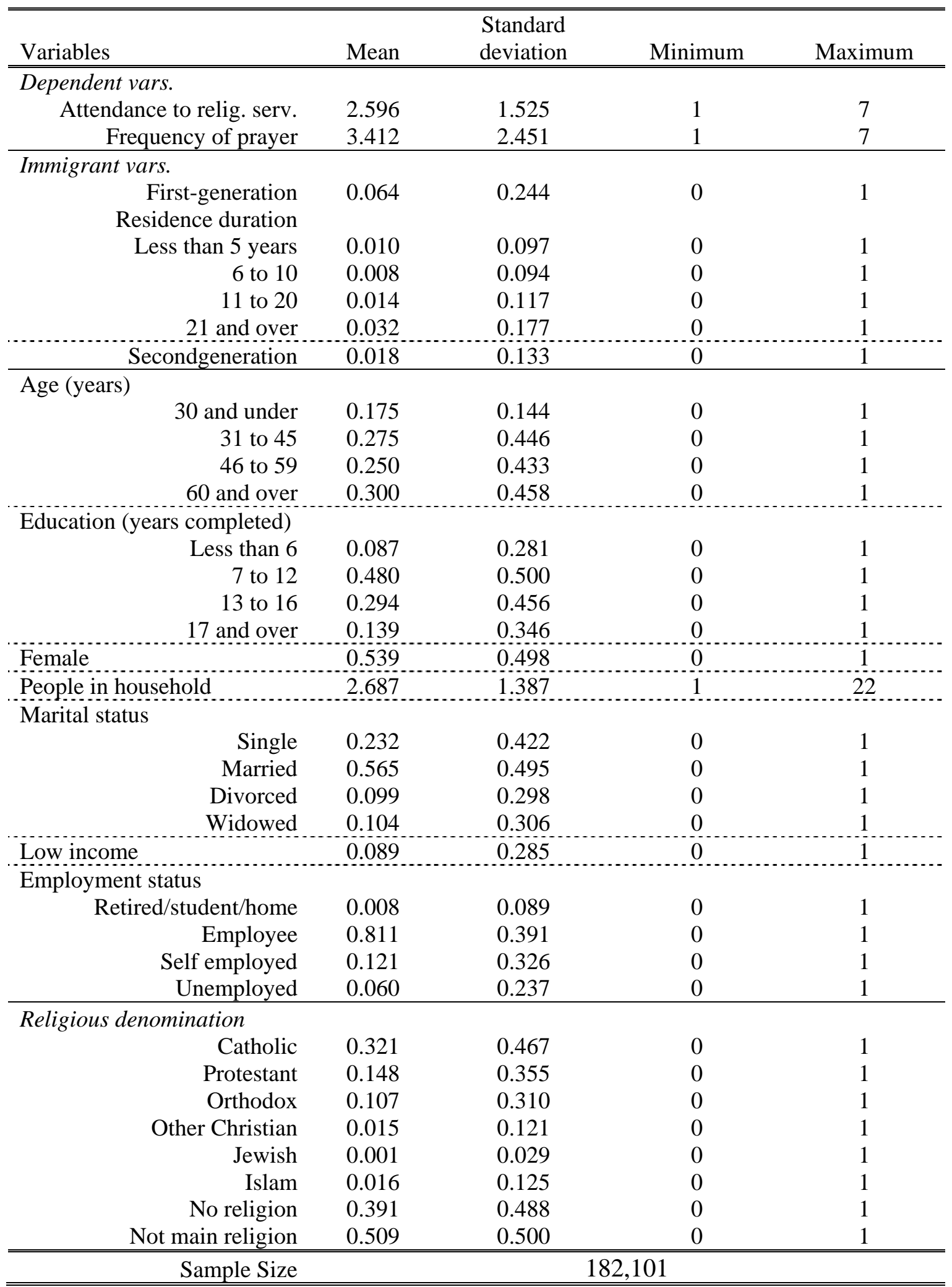


Table A.2. GSS-US: descriptive statistics

\begin{tabular}{|c|c|c|c|c|}
\hline Variables & Mean & $\begin{array}{l}\text { Standard } \\
\text { deviation }\end{array}$ & Minimum & Maximum \\
\hline \multicolumn{5}{|l|}{ Dependent vars. } \\
\hline Attendance torelig. serv. & 3.631 & 2.738 & 0 & 8 \\
\hline Frequency of prayer & 4.230 & 1.702 & 1 & 6 \\
\hline \multicolumn{5}{|l|}{ Immigrant vars. } \\
\hline Firstgeneration & 0.083 & 0.275 & 0 & 1 \\
\hline Secondgeneration & 0.034 & 0.180 & 0 & 1 \\
\hline \multicolumn{5}{|l|}{$\begin{array}{l}\text { Socio-economic vars. } \\
\text { Age (vears) }\end{array}$} \\
\hline 30 and under & 0.187 & 0.390 & 0 & 1 \\
\hline 31 to 45 & 0.314 & 0.464 & 0 & 1 \\
\hline 46 to 59 & 0.270 & 0.444 & 0 & 1 \\
\hline 60 and over & 0.229 & 0.420 & 0 & 1 \\
\hline \multicolumn{5}{|l|}{ Education (years completed) } \\
\hline Less than 6 & 0.024 & 0.153 & 0 & 1 \\
\hline 7 to 12 & 0.397 & 0.489 & 0 & 1 \\
\hline 13 to 16 & 0.442 & 0.497 & 0 & 1 \\
\hline 17 and over & 0.137 & 0.344 & 0 & 1 \\
\hline Female & 0.538 & 0.498 & 0 & 1 \\
\hline People in household & 2.434 & 1.392 & 1 & 12 \\
\hline \multicolumn{5}{|l|}{ Marital status } \\
\hline Single & 0.233 & 0.423 & 0 & 1 \\
\hline Married & 0.492 & 0.500 & 0 & 1 \\
\hline Divorced & 0.199 & 0.399 & 0 & 1 \\
\hline Widowed & 0.076 & 0.264 & 0 & 1 \\
\hline Low income & 0.070 & 0.255 & 0 & 1 \\
\hline \multicolumn{5}{|l|}{ Employment status } \\
\hline Retired/student/home & 0.309 & 0.462 & 0 & 1 \\
\hline Employee & 0.565 & 0.496 & 0 & 1 \\
\hline Self employed & 0.085 & 0.279 & 0 & 1 \\
\hline Unemployed & 0.041 & 0.199 & 0 & 1 \\
\hline \multicolumn{5}{|l|}{ Religious denomination } \\
\hline Catholic & 0.216 & 0.411 & 0 & 1 \\
\hline Black Protestant & 0.205 & 0.404 & & \\
\hline Evangelical Protestant & 0.232 & 0.422 & & \\
\hline Mainline Protestant & 0.129 & 0.335 & 0 & 1 \\
\hline Orthodox & 0.005 & 0.070 & 0 & 1 \\
\hline Other Christian & 0.030 & 0.169 & 0 & 1 \\
\hline Jewish & 0.018 & 0.132 & 0 & 1 \\
\hline Islam & 0.004 & 0.064 & 0 & 1 \\
\hline No religion & 0.161 & 0.369 & 0 & 1 \\
\hline Not main religion & 0.737 & 0.440 & 0 & 1 \\
\hline Sample Size & \multicolumn{4}{|c|}{11,440} \\
\hline
\end{tabular}

